\title{
CMEARTICLE
}

\section{Developmental assessment: practice tips for primary care physicians}

Ying Ying ${\underline{C h o 0^{1}}}^{1}$, MD, Sita Padmini Yeleswarapu${ }^{2}$, MBBS, FRCPCH, Choon How $\underline{H o w}^{3,4}$, MMed, FCFP, Pratibha $\underline{A g a r w a l}^{2}$, MD, MMed

Felicia's parents brought their 12-month-old girl to your clinic for routine vaccinations. They expressed concern that she was not walking yet and reported that she had been able to sit independently at eight months and crawl at nine months. Felicia could pull herself up to stand while holding on to the bed rails. Her birth and medical history were unremarkable. She looked active and her physical examination results were within normal limits.

\section{WHAT IS CHILD DEVELOPMENT?}

Child development refers to the continuous but predictably sequential biological, psychological and emotional changes that occur in human beings between birth and the end of adolescence. The sequence of development is the same for all children and can be described in terms of developmental milestones. As children develop at different rates, which are determined by a complex interplay of environmental and genetic factors, ${ }^{(1)}$ the age of attainment for each milestone ranges widely. It is essential to not only be aware of the median age of attainment of the milestone (i.e. the age at which half of the standard population achieves the milestone) but the limit age as well (i.e. the upper age limit at which the particular milestone should have been achieved). This would help to guide the clinician on whether to reassure the parent/caregiver, monitor the child's development closely or refer the child to a specialist for a detailed assessment and further management. It is also essential for the clinician to assess the quality of the skill rather than taking note of the age at which the milestone was achieved. For example, a child may have acquired sufficient language skills to allow him to speak in phrases, but may be unskilled in using language for conversational purposes.

The basic architecture of the brain is constructed by an ongoing process that begins before birth and continues into adulthood. Maximum brain development occurs within the first three years of a child's life and is hence called the early developmental phase. It is therefore essential to recommend that parents engage in appropriate stimulation activities with their children, starting from the newborn period.

\section{HOW RELEVANT IS THIS TO MY PRACTICE?}

In Singapore, every well child is scheduled to be seen at specific ages by a trained nurse or a doctor for a developmental screening, according to the child health surveillance programme at the polyclinics and in line with practice guidelines endorsed by the American Academy of Pediatrics. ${ }^{(2)}$ The child's health booklet provides guidelines on the time points when developmental screening should occur, as part of six recommended touch points between the ages of one month and 4-6 years. The developmental checklist in the health booklet is based on the Denver Developmental Screening Test, which is the only tool standardised for the local population (DDST-Singapore). ${ }^{(3)}$ As the cut-offs indicate 90th percentile norms, if a child is unable to achieve a milestone for the stated age (indicating that $90 \%$ of the same age population is able to achieve it), a more in-depth assessment and a low threshold for further specialist referral are required. The parents and professionals working with the child are responsible for updating the developmental checklist, which provides guidelines to monitor the child's development.

It is common for children to attend fewer developmental screening appointments after the age of 18 months. Hence, it is essential that primary care physicians conduct developmental surveillance, which is an informal yet structured monitoring of developmental status over time. The components of developmental surveillance include eliciting and addressing parents' concerns about their child's development (Box 1); obtaining a developmental history (Box 2); making precise observations of the child; identifying risk and protective factors; and lastly, making effective documentation of the

\section{Box 1. Developmental surveillance questions:}

1. Do you have any concerns about your child's development, behaviour or learning?

2. What concerns do you have about your child?

3. Age- and domain-specific queries, e.g. to evaluate language in an 18-month-old child, you could ask, 'How does your child communicate with you?'

4. How has your child's development improved since the last visit?

\footnotetext{
${ }^{1}$ SingHealth Polyclinics - Sengkang, ${ }^{2}$ Department of Paediatrics, Child Developmental Service, KK Women's and Children's Hospital, ${ }^{3} \mathrm{Care}$ and Health Integration, Changi General Hospital, ${ }^{4}$ Family Medicine Academic Clinical Programme, SingHealth Duke-NUS Academic Medical Centre, Singapore

Correspondence: Dr Choo Ying Ying, Family Medicine Resident, SingHealth Polyclinics - Sengkang, 2 Sengkang Square, Sengkang Community Hub, \#01-06, Singapore 545025. yingying.choo@mohh.com.sg
} 


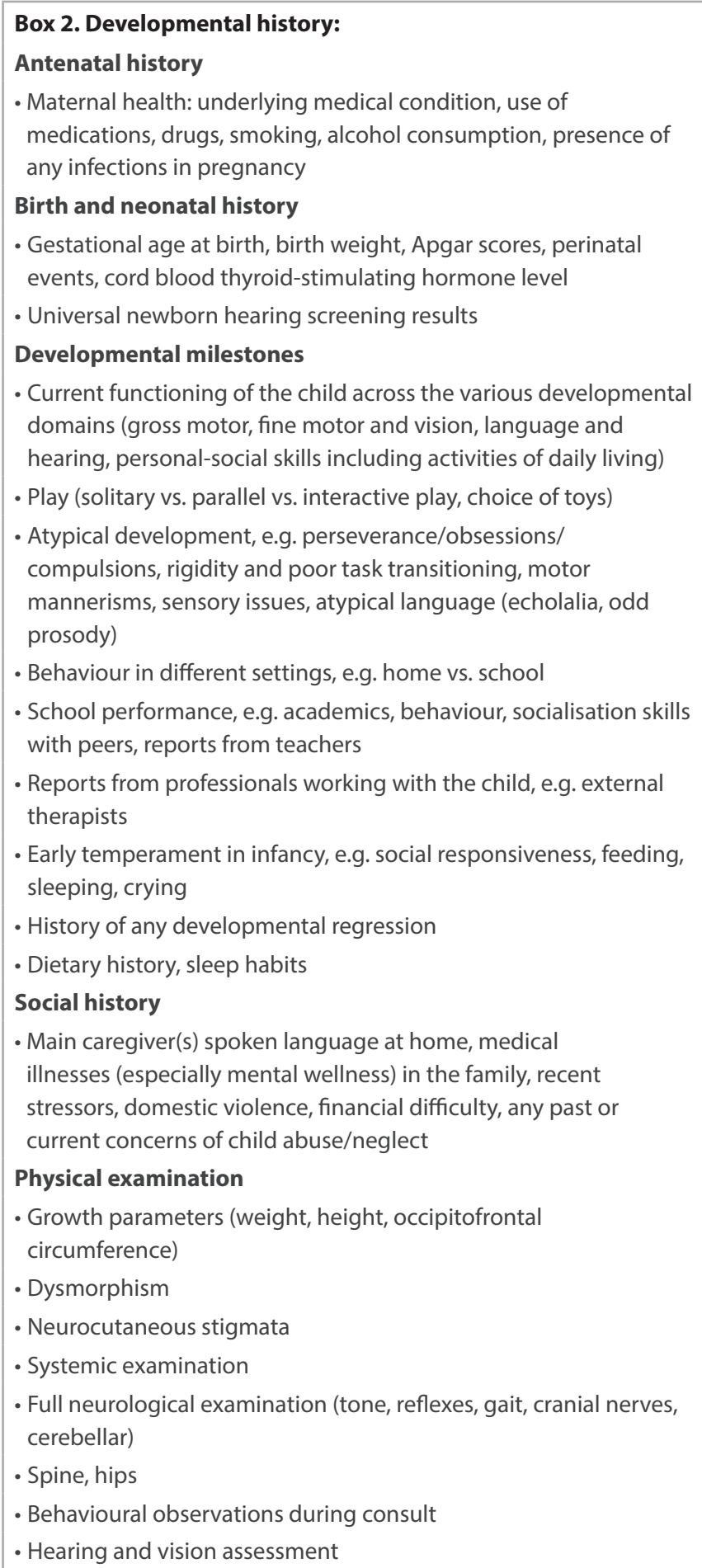

obtained history and observation of the child. ${ }^{(2,4)}$ Any concerns raised during surveillance should be promptly addressed with standardised developmental screening tools, which help to identify the child's risk of developmental delay. Developmental screening questionnaires that are commonly used in our local setting are listed in Table I. The next article in this two-part series will cover developmental delays and management.
When the parents or preschool raises concerns about developmental delay, paediatricians and primary care physicians are the first points of contact for parents seeking reassurance or further assessment. Therefore, primary care physicians need to have a systematic approach when evaluating a child for development, including taking a developmental history, conducting a developmental assessment and being aware of the red flags that would warrant further specialist referrals when necessary. In the absence of any concerns, parental anxiety should be allayed. Knowledge of developmental milestones is essential for the primary care physician to be able to provide anticipatory guidance and suggest appropriate activities to the parents or caregivers so that they can facilitate the next stage of development.

\section{COMMON PITFALLS AND CHALLENGES IN ROUTINE PRACTICE}

Not all parents take their children to developmental screening assessments after the primary immunisations are completed at 18 months of age. A study conducted in Singapore of parents of children aged 30-47 months indicated that only one in four parents took their child to the $2-3$ year developmental monitoring visit. ${ }^{(10)}$ The same study highlighted that only about half of the parents attempted to complete the checklist. Another challenge is the time constraint from implementing developmental surveillance during busy clinics. ${ }^{(11)}$ Success of developmental surveillance depends on continuous monitoring of the child and may not work well for children who receive infrequent care by different professionals. There is also variability in child development knowledge and training among front-line practitioners. ${ }^{(12)}$

\section{WHAT CAN I DO IN MY PRACTICE?}

As child stimulation starts at birth, primary care physicians should advise parents on appropriate child stimulation activities at every available opportunity. While the developmental checklist in the baby health booklet can be used to monitor the child's development, it is brief; hence, there is a need to adopt a standardised screening tool to conduct developmental screening during the vital touch points (Fig. 1). ${ }^{(4,13)}$ Developmental surveillance should also be conducted at every clinic visit. If the developmental surveillance identifies any concerns, the physician should follow up with a developmental screening assessment. Concerns raised through the assessment would warrant further specialist referral as deemed necessary. When development age in any domain is after the median age but still within the 90th percentile, anticipatory guidance on various stimulation methods and activities should be given to the family, along with closer monitoring in the form of a follow-up visit. Parents should be encouraged to monitor their child's development regularly using the health booklet. Physicians should also be aware of other factors that affect development, such as sleep, diet and family circumstances. 
Table I. Developmental screening questionnaires.

\begin{tabular}{|c|c|c|c|c|c|}
\hline Instrument & Domains covered & Age & $\begin{array}{l}\text { Method of } \\
\text { administration }\end{array}$ & $\begin{array}{l}\text { Sensitivity and } \\
\text { specificity }\end{array}$ & $\begin{array}{l}\text { Time to } \\
\text { administer }\end{array}$ \\
\hline ASQ-3(5,6) & $\begin{array}{l}\text { - Communication, gross } \\
\text { motor, fine motor, } \\
\text { problem-solving and } \\
\text { personal-social }\end{array}$ & $1-66 \mathrm{mth}$ & $\begin{array}{l}\text { Parent } \\
\text { completed }\end{array}$ & $\begin{array}{l}\text { Moderate to high } \\
\text { sensitivity and } \\
\text { specificity }\end{array}$ & $10-15 \mathrm{~min}$ \\
\hline $\operatorname{PEDS}^{(7)}$ & $\begin{array}{l}\text { - Global/cognitive } \\
\text { - Language and articulation } \\
\text { - Gross motor and fine motor, } \\
\text { behaviour and social-emotional } \\
\text { - Self-help and school }\end{array}$ & $0-8 \mathrm{yr}$ & $\begin{array}{l}\text { Parent } \\
\text { completed }\end{array}$ & $\begin{array}{l}\text { Moderate } \\
\text { sensitivity and } \\
\text { specificity }\end{array}$ & $5-10 \mathrm{~min}$ \\
\hline Brigance Screens ${ }^{(8)}$ & $\begin{array}{l}\text { - Expressive and receptive language } \\
\text { - Gross motor and fine motor } \\
\text { - Academics }\end{array}$ & $0-7 \mathrm{yr}$ & $\begin{array}{l}\text { Directly } \\
\text { administered }\end{array}$ & $\begin{array}{l}\text { Moderate to high } \\
\text { sensitivity, moderate } \\
\text { specificity }\end{array}$ & $15 \mathrm{~min}$ \\
\hline $\mathrm{DDST}^{(8)}$ & $\begin{array}{l}\text { - Expressive and receptive language, } \\
\text { gross motor, fine motor } \\
\text { - Personal-social skills }\end{array}$ & 2-71 mth & $\begin{array}{l}\text { Directly } \\
\text { administered }\end{array}$ & $\begin{array}{l}\text { Low to moderate } \\
\text { sensitivity and } \\
\text { specificity }\end{array}$ & $15-25 \mathrm{~min}$ \\
\hline $\mathrm{M}-\mathrm{CHAT}^{(9)}$ & $\begin{array}{l}\text { - Screening tool for autism spectrum } \\
\text { disorder }\end{array}$ & $16-30 \mathrm{mth}$ & $\begin{array}{l}\text { Parent } \\
\text { completed }\end{array}$ & $\begin{array}{l}\text { Moderate sensitivity, } \\
\text { high specificity }\end{array}$ & $5-10 \mathrm{~min}$ \\
\hline
\end{tabular}

ASQ-3: Ages and Stages Questionnaire; DDST: Denver Developmental Screening Test; M-CHAT: Modified Checklist for Autism in Toddlers; PEDS: Parents' Evaluation of Developmental Status

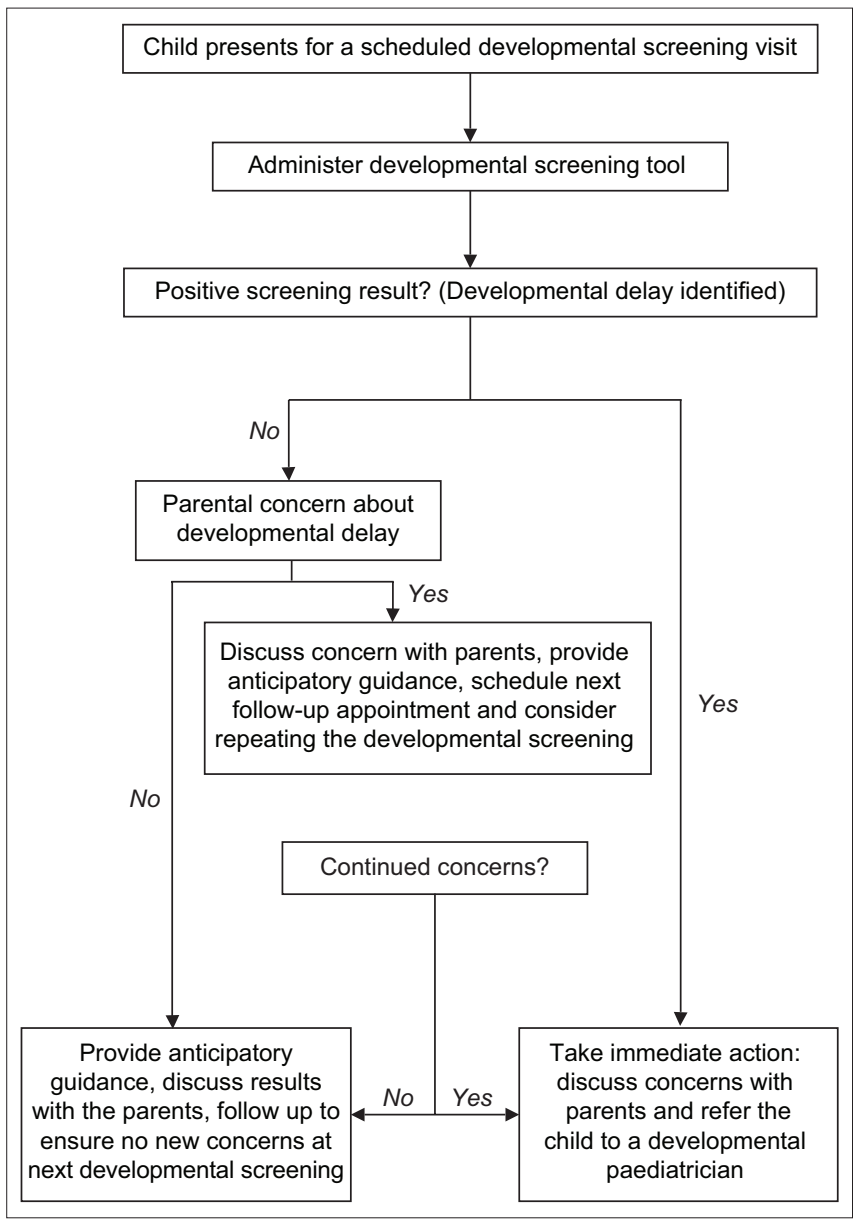

Fig. 1 Flowchart shows the algorithmic approach to developmenta screening. ${ }^{(4)}$ Adapted and modified from the Centers for Disease Control and Prevention. ${ }^{(13)}$

\section{TAKE HOME MESSAGES}

1. The role of parents in early childhood stimulation is crucial for child developmental.

2. Developmental surveillance should be incorporated in every child visit. When a concern is raised, this should be followed up with a developmental screening assessment.

3. Developmental screening should be performed at specific ages.

4. Parents and families should be encouraged to use the child's health booklet.

You conducted a detailed developmental assessment for Felicia and noticed that all developmental milestones were appropriate for her age. Her health booklet revealed no concern during the developmental screening conducted at nine months of age. You reassured her parents that Felicia was developing normally for her age. You explained that most children commence walking at 12 months of age, and that the normal limit for starting to walk was up to the age of 16 months. You advised Felicia's parents to continue monitoring her development by using the health booklet checklist and arranged a follow-up visit three months later to monitor the progression of her gross motor skills. 
ABSTRACT Child development refers to the continuous but predictably sequential biological, psychological and emotional changes that occur in human beings between birth and the end of adolescence. Developmental surveillance should be incorporated into every child visit. Parents play an important role in the child's developmental assessment. The primary care physician should educate and encourage parents to use the developmental checklist in the health booklet to monitor their child's development. Further evaluation is necessary when developmental delay is identified. This article aimed to highlight the normal child developmental assessment as well as to provide suggestions for screening tools and questions to be used within the primary care setting.

Keywords: child developmental, developmental screening tools, primary care surveillance

\section{REFERENCES}

1. Champagne FA. Early adversity and developmental outcomes interaction between genetics, epigenetics, and social experiences across the life span. Perspect Psychol Sci 2010; 5:564-74.

2. Council on Children With Disabilities; Section on Developmental Behavioral Pediatrics; Bright Futures Steering Committee; Medical Home Initiatives for
Children With Special Needs Project Advisory Committee. Identifying infants and young children with developmental disorders in the medical home: an algorithm for developmental surveillance and screening. Paediatrics 2006; 118:405-20.

3. Lim HC, Chan T, Yoong T. Standardisation and adaptation of the Denver Developmental Screening Test (DDST) and Denver II for use in Singapore Children. Singapore Med J 1994; 35:156-60.

4. Vitrikas K, Savard D, Bucaj M. Developmental delay: when and how to screen. Am Fam Physician 2017; 96:36-43.

5. Hamilton S. Screening for developmental delay: reliable, easy-to-use tools. J FamPract 2006; 55:415-22.

6. Ages and Stages Questionnaires. Commonly Used Parent-Report Developmental Screening Tools. Available at http://agesandstages.com/wp-content/ uploads/2015/03/Comparison-Chart1.pdf. Accessed February 14, 2016.

7. Kiing JS, Low PS, Chan YH, Neihart M. Interpreting parents' concerns about their children's development with the Parents Evaluation of Developmental Status: culture matters. J Dev Behav Pediatr 2012; 33:179-83.

8. Ringwalt S. Developmental Screening and Assessment Instruments with an Emphasis on Social and Emotional Development for Young Children Ages Birth through Five. National Early Childhood Technical Assistance Center 2008. Available at: http://www.nectac.org/ pdfs/pubs/screening.pdf. Accessed December 11, 2015.

9. Koh HC, Lim SH, Chan GJ, et al. The clinical utility of the modified checklist for autism in toddlers with high risk 18-48 month old children in Singapore. J Autism Dev Disord 2014; 44:405-16.

10. Koh HC, Ang SK, Kwok J, et al. The utility of developmental checklists in parentheld health records in Singapore. J Dev Behav Pediatr 2016; 37:647-56.

11. Rydz D, Shevell M, Majnemer A, Oskoui M. Topical review: developmental screening. J Child Neurol 2005; 20:4-21.

12. Lian WB, Ho SK, Yeo CL, Ho LY. General practitioners' knowledge on childhood developmental and behavioural disorders. Singapore Med J 2003; 44:397-403.

13. Centers for Disease Control and Prevention. Developmental Monitoring and Screening for Health Professionals. Available at: https://www.cdc.gov/ncbddd/ childdevelopment/screening-hcp.html. Accessed January 11, 2019. 


\section{APPENDIX}

\section{Normal developmental milestones}

\begin{tabular}{|c|c|c|c|c|c|}
\hline Age & Gross motor & Fine motor and vision & $\begin{array}{l}\text { Hearing, language } \\
\text { (e = expressive, } r=\text { receptive) }\end{array}$ & Personal-social & Red flags \\
\hline Birth & $\begin{array}{l}\text { Significant head lag; presence of } \\
\text { primitive reflexes }\end{array}$ & $\begin{array}{l}\text { Turns eyes to large and diffuse source } \\
\text { of light }\end{array}$ & $\begin{array}{l}\text { Has startle reaction to sudden loud } \\
\text { sounds }\end{array}$ & $\begin{array}{l}\text { Cries when hungry or } \\
\text { uncomfortable }\end{array}$ & Floppy baby \\
\hline $6 \mathrm{wk}$ & $\begin{array}{l}\text { Head in line with body in ventral } \\
\text { suspension }\end{array}$ & Fixes and follows past midline & Becomes still in response to sound & Social smile & $\begin{array}{l}\text { Unresponsive to sound or visual } \\
\text { stimuli }\end{array}$ \\
\hline $3 \mathrm{mth}$ & $\begin{array}{l}\text { Holds head at } 45^{\circ}-90^{\circ} \text { in ventral } \\
\text { suspension; props up on forearms }\end{array}$ & $\begin{array}{l}\text { Hands unfisted, holds object placed in } \\
\text { the hand } \\
\text { Fixes and follows past midline }\end{array}$ & Turns to sound; coos and laughs & Hand regard, laughs and squeals & $\begin{array}{l}\text { Lack of social response or } \\
\text { vocalisation }\end{array}$ \\
\hline $6 \mathrm{mth}$ & $\begin{array}{l}\text { Rolls over, no head lag on pull to sit, } \\
\text { sits with support }\end{array}$ & $\begin{array}{l}\text { Reaches for objects; transfers objects } \\
\text { hand to hand }\end{array}$ & Babbles (non-specific) & Stranger anxiety & $\begin{array}{l}\text { Poor head control, not reaching for } \\
\text { objects; no babbling }\end{array}$ \\
\hline $9 \mathrm{mth}$ & $\begin{array}{l}\text { Sits steadily when unsupported, crawls, } \\
\text { pulls to stand and stands with support }\end{array}$ & $\begin{array}{l}\text { Immature pincer grasp of objects; bangs } \\
\text { two cubes held in hand }\end{array}$ & $\begin{array}{l}\text { Understands 'no' and 'bye'(r); says } \\
\text { 'mama' and 'papa' non-specifically (e) }\end{array}$ & $\begin{array}{l}\text { Waves bye; claps hands; plays } \\
\text { peek-a-boo }\end{array}$ & $\begin{array}{l}\text { Unable to sit without support; } \\
\text { does not transfer objects }\end{array}$ \\
\hline $12 \mathrm{mth}$ & $\begin{array}{l}\text { Stands without support; walks with one } \\
\text { hand held }\end{array}$ & Mature pincer grasp; casts objects & $\begin{array}{l}\text { Follows one step command with } \\
\text { gesture (r); says 'mama,'papa' and } \\
2-3 \text { other words with meaning (e) }\end{array}$ & $\begin{array}{l}\text { Points to indicate wants; imitates } \\
\text { gestures; plays with cause-and- } \\
\text { effect toys; drinks from a cup }\end{array}$ & $\begin{array}{l}\text { Unable to stand with support; } \\
\text { not using social gestures, such as } \\
\text { pointing, waving }\end{array}$ \\
\hline $18 \mathrm{mth}$ & $\begin{array}{l}\text { Walks well ( } 15 \mathrm{mth}) \text {; stoops and recovers; } \\
\text { walks up stairs with one hand held }\end{array}$ & Builds tower of three cubes; scribbles & $\begin{array}{l}\text { Follows one-step command without } \\
\text { gesture (r); around } 10 \text { single words } \\
\text { with meaning (e) }\end{array}$ & $\begin{array}{l}\text { Parallel play, symbolic play: 'talking' } \\
\text { on telephone; domestic mimicry; } \\
\text { eats with a spoon }\end{array}$ & $\begin{array}{l}\text { Not walking independently; no } \\
\text { meaningful single words }\end{array}$ \\
\hline $2 \mathrm{yr}$ & $\begin{array}{l}\text { Runs well; kicks ball, jumps with both feet } \\
\text { off ground, climbs stairs, } 2 \text { feet per step }\end{array}$ & $\begin{array}{l}\text { Builds tower of } 6-7 \text { cubes, circular } \\
\text { scribbles, copies a vertical line }\end{array}$ & $\begin{array}{l}\text { Follows two-step command (r); says } \\
\text { two- to three-word phrases (e) }\end{array}$ & $\begin{array}{l}\text { Parallel play, two-step pretend play } \\
\text { such as chopping vegetables and } \\
\text { serving; shows defiant behaviour }\end{array}$ & $\begin{array}{l}\text { Unable to walk up stairs with help; } \\
\text { no spontaneous two-word phrases }\end{array}$ \\
\hline $3 \mathrm{yr}$ & $\begin{array}{l}\text { Stands briefly on one foot; walks up and } \\
\text { down stairs with alternate feet; pedals a } \\
\text { tricycle }\end{array}$ & Builds tower of nine cubes, copies a circle & $\begin{array}{l}\text { Follows three-step command (r); } \\
\text { says three- to four-word phrases (e); } \\
\text { identify shapes*; matches colours* }\end{array}$ & $\begin{array}{l}\text { Interactive play, dresses and } \\
\text { undresses with help; eats with fork } \\
\text { and spoon; toilet-trained }\end{array}$ & $\begin{array}{l}\text { Unable to run or jump up; no two- } \\
\text { to three-word phrase; engages in } \\
\text { solitary play }\end{array}$ \\
\hline $4 \mathrm{yr}$ & $\begin{array}{l}\text { Hops on one foot; has skills in ball games } \\
\text { (throwing, catching, bouncing) }\end{array}$ & Builds tower of 12 blocks; copies a square & $\begin{array}{l}\text { Can follow'wh' questions (what, } \\
\text { where); speaks grammatically } \\
\text { and correctly; uses pronouns and } \\
\text { prepositions; knows four colours*; } \\
\text { able to rote count 1-10* }\end{array}$ & $\begin{array}{l}\text { Role-play with friends; independent } \\
\text { in day-to-day activities }\end{array}$ & $\begin{array}{l}\text { Unable to hop on one leg; } \\
\text { cannot follow two- to three-step } \\
\text { command; no colour recognition }\end{array}$ \\
\hline $5 \mathrm{yr}$ & $\begin{array}{l}\text { Stands on one foot for } 10 \text { seconds; skips; } \\
\text { rides a bicycle }\end{array}$ & $\begin{array}{l}\text { Copies a triangle; draws a person with } \\
6-8 \text { body parts }\end{array}$ & $\begin{array}{l}\text { Can follow'why' and 'how' } \\
\text { questions; speaks fluently with long } \\
\text { descriptions; tells stories; recognises } \\
\text { numbers 1-10 and the alphabet* }\end{array}$ & $\begin{array}{l}\text { Has a group of friends; follows rules } \\
\text { with games }\end{array}$ & $\begin{array}{l}\text { Unable to give narratives; no } \\
\text { interactive play; no alphabet and } \\
\text { number recognition }\end{array}$ \\
\hline
\end{tabular}




\section{SINGAPORE MEDICAL COUNCIL CATEGORY 3B CME PROGRAMME} (Code SMJ 201902A)

1. There are eight touch points between birth and 4-6 years, according to the child health surveillance programme in Singapore.

2. The cut-offs indicated in the developmental checklist in the health booklet correspond to the 90th percentile norms.

3. Adjustment of the developmental age is required for children born at 37 weeks.

4. The developmental checklist in the health booklet is based on the Denver Developmental Screening Test, Singapore, which is the only screening tool that has been standardised for the local population.

5. Babies have a startle reaction to sudden loud noises only after their hearing pathways are developed, which is after six weeks of age.

6. Lack of a social smile by eight weeks is a red flag.

7. Unfisting of hands in babies is seen at around six months of age.

8. Mature pincer grasp occurs by the age of 12 months.

9. Pointing to indicate needs occurs at around 18 months of age.

10. Inability to sit independently without support by six months is a red flag that warrants a specialist referral.

11. A child should start speaking in sentences by two years of age.

12. No alphabet or number recognition by the age of five years is a red flag.

13. A two-year-old child engaging in parallel play is a cause for concern and warrants further assessment.

14. Interactive play develops at around the age of three years.

15. If a child passes the newborn hearing screen, there is no need to assess hearing later.

16. If a child presents with fine motor delay, the evaluation should also include vision assessment, as vision and fine motor skills are interlinked.

17. If a child's development occurs after the median age, but within the 90th percentile range, it warrants a specialist referral.

18. Poor sleep can impact child development.

19. Parents' Evaluation of Developmental Status is a parent-completed developmental screening questionnaire.

20. M-CHAT is a diagnostic assessment tool for autism spectrum disorder.

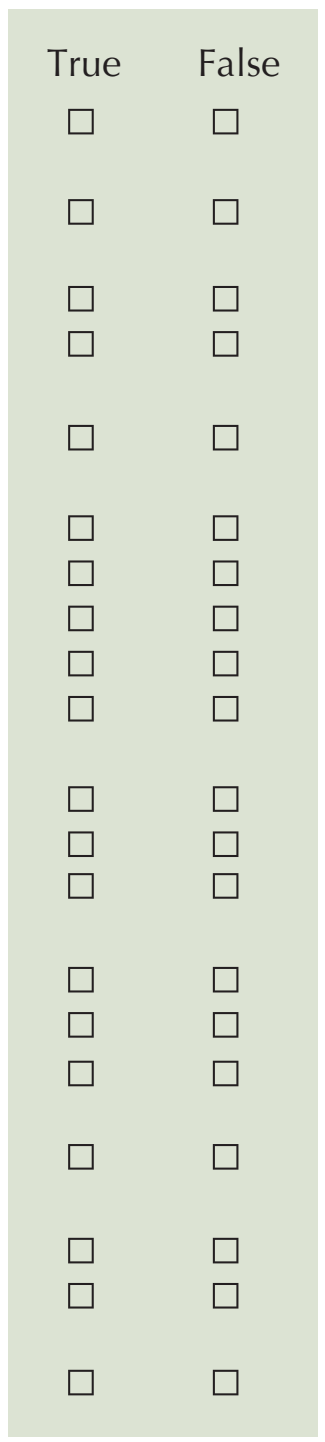

\section{Doctor's particulars:}

Name in full:

MCR no.:

Specialty:

Email:

\footnotetext{
SUBMISSION INSTRUCTIONS:

Visit the SMJ website: http://www.smj.org.sg/current-issue and select the appropriate quiz. You will be redirected to the SMA login page.

For SMA member: (1) Log in with your username and password (if you do not know your password, please click on 'Forgot your password?'). (2) Select your answers for each quiz and click 'Submit'.

For non-SMA member: (1) Create an SMJ CME account, or login with your SMJ CME username and password (for returning users). (2) Make payment of SGD 21.40 (inclusive of $7 \%$ GST) via PayPal to access this month's quizzes. (3) Select your answers for each quiz and click 'Submit'.

RESULTS:

(1) Answers will be published online in the SMJ April 2019 issue. (2) The MCR numbers of successful candidates will be posted online at the SMJ website by 15 April 2019. (3) Passing mark is $60 \%$. No mark will be deducted for incorrect answers. (4) The SMJ editorial office will submit the list of successful candidates to the Singapore Medical Council. (5) One CME point is awarded for successful candidates. (6) SMC credits CME points according to the month of publication of the CME article (i.e. points awarded for a quiz published in the December 2017 issue will be credited for the month of December 2017, even if the deadline is in January 2018).

Deadline for submission: (February 2019 SMJ 3B CME programme): 12 noon, 7 April 2019.
} 